\title{
The Effects of Practice on the Armed Services Vocational Aptitude Battery
}

\author{
Bruce K. McCormick and William P. Dunlap \\ Tulane University \\ Robert S. Kennedy \\ Essex Corporation \\ Marshall B. Jones \\ Hershey Medical Center \\ Selection and Classification Technical Area \\ Manpower and Personnel Research Laboratory
}

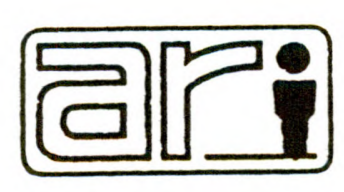

U. S. Army

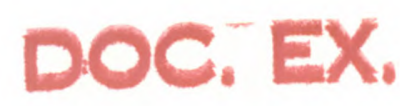

\section{MAR 181985}

UNIVERSIFY OF ILLINOIS AT URRANA:CHAMPAICN

Research Institute for the Behavioral and Social Sciences

$$
\text { December } 1983
$$

Approved for public release: distribution unlimited. 